\title{
ACTIVE PARTICIPATION IN THE STUDENT-TO- TEACHER INTERACTION IN ONLINE SYNCHRONOUS SESSIONS IN HIGHER EDUCATION
}

\section{La participación activa en la interacción estudiante-docente en clases síncronas en línea en Educación Superior}

Catalina Juárez-Díaz'

catalinajuarezdiaz@gmail.com

Leonel Ojeda-Ruiz'

leojedaruiz@gmail.com

${ }^{1}$ Benemérita Universidad Autónoma de Puebla. México

Recibido: $16 / 02 / 2021$

Revisado: 21/04/2021

Aprobado: $16 / 05 / 2021$

Preprint: 20/06/2021

Publicado: 15/07/2021

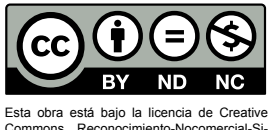

\section{Abstract}

Mexican institutions promoted e-learning to conclude the school year 20192020. In the higher education institution where this study was conducted, teachers were not familiar with online teaching. In Spring 2020, teachers prepared themselves or with students' assistance to teach online. In Summer 2020, the institution offered workshops to update teachers on Blackboard LMS, Microsoft Teams, and Moodle to work in Autumn 2020. After that training, teachers started videoconferences in online synchronous sessions (OSSs). However, they observed that students did not participate actively in OSSs. Given this contextual background, this qualitative exploratory study addressed a threefold objective: 1 . To identify students' perceptions of active participation in OSSs. 2. To explore the degree of participation in the student-teacher interaction in OSSs at a higher institution, and 3. To identify factors affecting student active participation while teachers are lecturing. Sixteen participants with ages ranging from 19 to 25 years old were interviewed. The results showed that most participants consider active participation essential in online synchronous sessions; the level of participation was high, moderate, and low. In addition, affective, cognitive, moral and technical factors affected students' active participation. The results of this study are useful in shaping our understanding of the whole panorama that is taking place behind synchronous sessions.

Keywords: e-learning, student-to-teacher interaction, synchronous interaction, active participation, higher education

\section{Resumen}

Las instituciones mexicanas impulsaron el aprendizaje en línea para concluir el año escolar 2019-2020. En la institución de educación superior donde se realizó este estudio, los profesores no estaban familiarizados con la enseñanza en línea. En la primavera de 2020, los maestros se prepararon ellos mismos o con la ayuda de los estudiantes para enseńar en línea. En verano de 2020, la institución ofreció talleres para actualizar a los maestros sobre Blackboard LMS, Microsoft Teams y Moodle para trabajar en otoño de 2020. Después de esa capacitación, los maestros comenzaron a impartir videoconferencias en sesiones síncronas en línea (SSL). Sin embargo, observaron que los estudiantes no participaban activamente en las SSL. Teniendo en cuenta estos antecedentes contextuales del estudio, este estudio cualitativo exploratorio abordó un triple objetivo: 1) identificar las percepciones de los participantes sobre la participación activa en sesiones síncronas, 2) explorar el grado de participación en la interacción estudiante-docente en sesiones sincrónicas en una institución superior, 3) identificar los factores que afectan la participación activa de los estudiantes mientras los profesores están dando clases. Se entrevistó a 16 participantes de entre 19-25 ańos. Los resultados mostraron que la mayoría de los participantes consideran importante la participación activa; el nivel de participación fue alto, moderado y bajo y que los factores que influyen en la participación activa de los alumnos son de tipo afectivo, cognitivo, moral y técnico. Los resultados de este estudio son útiles para dar forma a nuestra comprensión del panorama que se está produciendo detrás de las sesiones síncronas.

Palabras clave: aprendizaje en línea, interacción estudiante-docente, interacción síncrona, participación activa, educación superior. 


\section{Introduction}

E-learning emerged thanks to the growth and incorporation of technology with academic purposes in education. Teachers and students need to learn how to use Information and Communication Technologies (ICTs) and keep in mind its importance in education nowadays (George-Reyes, 2021). In March 2020, all Mexican institutions started to promote e-learning, which allowed them to conclude the school year 2019-2020. E-learning has some advantages: one of them is to work anytime, anywhere. It permits teachers and students to interact synchronously and asynchronously (Torun, 2013). Both kinds of interaction are expected to engage students in e-learning where active participation is necessary as students' qualitative and quantitative participation in synchronous and asynchronous interaction correlates to the course's general performance and the results of the final exam (Duncan et al., 2012). Therefore, e-learning requires interactive participation to exchange ideas and teacher-student discussion where chats are a good option to promote spontaneous interaction and engagement to learning (Davidson-Shivers et al., 2001). Ng (2007) agrees on the importance of interaction since it is a basic worthy element of the teaching-learning process because learners can communicate, get feedback and be corrected. Synchronous interaction facilitates teaching and learning since students' participation and production can be supervised; also, students can be advised to use the language accurately and invited to revise and correct what they are producing timely (Lee, 2002). Many teachers use synchronous interaction because they can have discussions with their students, which are necessary for learning. Interaction between learners and facilitators is necessary because they can negotiate meaning and verify understanding, which ends up in knowledge (Chen et al., 2015).

In two previous studies done in this same institution in the contingency period, Juárez Díaz (2020) and Juárez Díaz and Perales (in press) found that teachers promoted online asynchronous sessions. In the asynchronous interaction, teachers selected platforms such as Google Classroom, Edmodo, and Moodle to send, retrieve, store and provide feedback for students' assignments. However, students did not find this kind of interaction convenient since they considered that they needed to be working in online synchronous sessions to verify understanding and express doubts. They needed their teacher presence to confirm if what they were doing was correct and realized whether they were learning. However, teachers considered that although learners had many opportunities to participate in online synchronous sessions, student participation was low. In the same vein, Wang et al. (2018) found that student's participation in online synchronous sessions is low and interaction is negatively affected since students are not acquainted with each other and every member is strange. Other aspects that affect student interaction are the students' pace and rhythm to work and the long lecturing time since students must wait until discussion is enhanced $(\mathrm{Ng}, 2007)$. Teachers report that students shut down their cameras and do not answer when teachers call them out (Chen et al., 2015; Cunningham, 2014). As Macnaught and Yates (2020) put it, "long periods of silence may mean students are actively completing the set task, distracted by their mobile phone, have taken a bathroom break, or are examining the contents of their fridge!" (p. 103). Based on these findings, teachers of this study assume that their students $\log$ in to the online sessions, are not in the online class, and may be doing something else, leaving the cameras and microphones off and going elsewhere. This exploratory qualitative study was done with the purpose to identify students' perceptions about active participation in synchronous classes. Second, to explore the degree of participation in the student-to teacher interaction in online synchronous sessions in a higher education institution. Finally, to identify the factors that affect student-teacher participation while teachers are lecturing.

\section{Literature Review}

\subsection{Interaction}

Online teachers can engage students in synchronous classes by promoting active student-facilitator 


\section{Revista Caribeña de Investigación Educativa | 2021, 5(2), 52-67}

interaction. It is considered "the learner's engagement with the course content, other learners, the instructor, and the technological medium used in the course" (Thurmond \& Wambach, 2004, p. 4, cited in Martin et al., 2012, p. 229). The student-facilitator interaction is necessary to have successful learning outcomes (Anderson, 2003). However, in online synchronous sessions, this type of interaction may not be as much as it is necessary for knowledge construction. Students can modify their usual performance in online settings, which they manifest in face-to-face classes; some shy students who never participate in face-to-face learning have become more participative in online sessions; others have reduced their participation in online classes in comparison to the face-to-face ones. Therefore, teachers need to look for strategies to engage their students in the synchronous sessions to increase participation since it is essential to check comprehension and construct knowledge. It is advisable to motivate students to turn on their cameras, so the physical presence and the paralinguistic language increase since both aspects are essential in conveying meaning when social interactions occur (McBrien et al., 2009). It is also necessary to implement different strategies such as paraphrasing, summarizing, and reflection to promote participation. Another way to increase participation is to trace it and consider it an evaluation criterion (Olaniran, 2006).

Salmon (2011) provided a model for online work; it consists of five elements. The first one is access and motivation; in this stage, teachers and students need the essential tools to access the online setting and skills to work in this kind of learning-teaching environment and be motivated to interact. The second stage is the online socialization stage, which eases the construction of rapport and bonds between teachers and students. Stage three is called information exchange, where students collaboratively share content information and activities. Stage four is knowledge construction, where students, through information exchanges, can broaden their personal views with those of their partners and teachers. Stage five is development. Students become autonomous learners since they can employ and explore new learning experiences with the gained information in the previous stages.

\subsection{Types of interaction}

Different types of interaction have been promoted in e-learning, and they have contributed to students' learning. Moore (1989) proposed three types of interaction: the learner-to-content interaction, the learner-to-instructor interaction, and the learner-to-learner interaction. In the first one, learners self-direct the learning process. Students basically interact with the content, and learning is mediated with it, since "intellectually interacting with content results in learners' understanding, perspectives, and cognitive structures" (p. 2). The second one is where the instructor tests students, provides feedback, promotes interaction, self-direction, self-motivation, and keeps students interested in what the instructor teaches and motivates them to learn. The third type is vital since students interact among the group members to co-construct meaning among peers. Student-student interaction is more necessary for young learners who can get motivated by working in groups. Anderson (2003) considers that these interactions support understanding and learning and make it possible to have fulfilling learning experiences.

\subsection{Collaborative work to promote student-tea- cher interaction}

Several investigations have been conducted around the world analyzing the student-teacher interaction and the impact it has had in terms of student participation. For example, some studies have focused on participation in collaborative projects. In Australia, Simoff and Maher (2006) used a mixed-method approach in analyzing the participation of a group of students in collaborative design environments. They showed who had participated in synchronous communication and the extent of their contribution in asynchronous communication in the collaborative project. Likewise, in the UK, Holliman and Scanlon (2006) analyzed a postgraduate student group's participation when working on a report in computer-mediated conferences. Their results suggest that active participants were engaged in rich interactive discussions, and they worked cooperatively 
and collaboratively to produce their reports. In New Zealand, Macnaught and Yates (2020) report on creating online writing workshops for postgraduate research students using an online participation matrix. This study identified five types of student participation (from less to more demanding): observant, anonymous, episodic, concealed, and discursive. In the same vein, in Turkey, Çakiroğlu and Kılıç (2018) integrated social network game elements in online learning courses to enable students' participation in online learning courses and to interact with other classmates and the instructor. At the same time, they socialized, entertained themselves and kept motivated in the learning tasks.

There are some alternatives to interact on online learning experiences, such as augmented reality (AR), which contributes favorably to the learning outcomes, increases engagement and commitment of students (Yang \& Mei, 2018). When AR merges with game-based learning (GBL), they favor the learning results. Its fusion transforms authentic world images into a joyful learning experience. Thus, the combination of AR and games becomes augmented reality games (ARGs). They are fruitful learning tools to learn foreign languages (FLs) because everything is presented in the foreign language that helps students become independent learners and develop other digital, collaborative, critical thinking, problem-solving, communicative, and entrepreneurial skills. ARGs have great acceptance and value in online learning practices since they promote knowledge construction and students' skills (Rafiq \& Hashim, 2018). Another alternative to promote online learning is artificial intelligence, for example, chatbots. It is considered an engaging device that helps students learn the language by conversing in the FL, study, and remind them to do tasks (Pham et al., 2018).

\subsection{Online tools to promote student-teacher interaction}

Other studies have analyzed student-teacher interaction, specifically in chats, instant messaging and videoconferencing. In Hong Kong, Wu (2017) investigated the impact the teacher's presence had in synchronous chats with eight students from a Business English program. He found that the participants positively perceived the teacher's presence in a mobile chat project. The impact was noticed on an affective level as the students and the teacher improved their relationship and attitude; besides, the teacher's feedback boosted confidence in contributing more to the chats. Additionally, the students recognized the impact in terms of the teacher's role as a facilitator as he organized the project, provoked thought, facilitated participation, activated learner autonomy and eased up the atmosphere. In the UK, Burnett (2003) collected data from a monthly online chat between a group of trainee primary school teachers and herself to analyze the relationship between tutor move and student contribution. She found that tutor moves addressed social, organizational and intellectual aspects of discussion through online chat.

Similarly, Hrastinski (2006) investigated online participation in a Business English class using group work. His study results suggest that the groups that engaged in conversations via the instant messaging (IM) system (although used differently) had a higher level of participation, complementing rather than replacing e-mail communication. Instant messaging was particularly used for two specific functions: task support and information exchange, rather than social support. Likewise, Stewart et al. (2011) analyzed the way the instructor and the students were able to interact through videoconferencing technologies. They found that video conferencing promoted interaction between the instructor and the students and contributed to collaborative, intellectual exchanges of knowledge.

More studies have analyzed the experience of both synchronous and asynchronous communication. In the USA, Park and Bonk (2007) examined learning experiences in a synchronous communication delivery system in a graduate course in educational technology. According to their findings, students valued instructors' supports, multiple perspectives, meaningful interactions, and spontaneous feedback. Additionally, they found challenges regarding peers' network connection problems, tool-related 
problems, language barriers, lack of reflection, and time constraints. Finally, in Australia, Watson (2008) analyzed teachers' perceptions on the effective implementation of asynchronous discussion tools and the factors that affect student participation. In this preliminary study, she found that teachers underwent different teaching experiences, and the learning outcomes were affected by the teaching strategy they had used to achieve the desired outcome. Factors affecting student participation were the student cohort's characteristics, the teacher's online presence, assessment of student contributions, task/activity structure, and clarity of teacher's expectations.

Although this is not an extensive list of interaction-related projects, the previous studies reflect the interest of different researchers worldwide, which gives evidence of the importance that student-teacher interaction has taken in their particular studies.

\section{Method}

This qualitative exploratory study was chosen because this type of study allows the researchers to interpret the study's subjectivity (Bautista, 2011). The objective of this study is threefold: 1) It intends to identify the students' perceptions about active participation in online synchronous sessions. 2) It explores the degree of their participation in the student-to-teacher interaction in online synchronous sessions in a higher institution. 3) It seeks to identify the factors that affect student active participation while teachers are lecturing in online synchronous sessions. This study addressed the following research questions:

1. What are the students' perceptions about active participation in online synchronous sessions?

2. What is the level of participation in the student-to-teacher interaction in online synchronous session in a higher institution?

3. What factors affect student active participation while teachers are lecturing?

The research assumptions of this study were the following:
- Students who actively participate in online synchronous sessions reflect more interest in terms of knowledge of the topic and their final grades.

- Students who do not participate actively in online synchronous sessions are not attentive to the contents of the class.

\subsection{Participants}

The sampling process was voluntary, which means that invitations were sent to LEI students to participate in this study, and they voluntarily accepted to be part of the sample (Hernández Sampieri et al., 2014). The criteria to select the participants were that students were enrolled in the terms Spring and Autumn 2020 in the language major and had online synchronous sessions. The characteristics of the participants are the following: They are preservice teachers who are studying the Licenciatura en la Enseñanza del Inglés (LEI) program in a major university in central Mexico. They belonged to different generations, specifically, 2015, 2018 and 2019. They were in the fourth, sixth, seventh and eighth semesters at the time of the study. Their ages ranged from 19 to 25 years old. Ten participants were female and six were male. Because of ethical considerations, the participants' real names are not revealed; instead, they are referred to as P1 (Participant 1), P2 (Participant 2), P3 (Participant 3), and the like. They were informed about the objectives of the study, they agreed and signed up for informed consent.

\subsection{Instrument}

The interview protocol, which consisted of four phases (Castillo-Montoya, 2016), was the qualitative research technique followed to collect the data. The first phase allowed us to match the interview questions to the research questions. The researchers made sure that the questions helped retrieve the data to answer the research questions. In the second phase, four types of questions were considered to create the inquiry-based conversation between the researchers and the participants (See Appendix A). 
In the third phase, the interview questions were sent to three experts in methodology to verify the reliability of the instrument. The first judge's comment was that research question two would not be answered because in the interview questions (IQ) a question was missing to retrieve it. For this reason, one question (IQ 9) was added to the interview guide to solve that problem. The second and third judges indicated that the questions for the interview would let us gather the information to reach the objectives of the research.

In the fourth phase, the questions were read by a different student from the sample who shares the intended sample characteristics. He was asked to answer the interview questions; thus, understanding of the questions was corroborated. Once the four phases were accomplished, the interviews were conducted. Before carrying out the interviews, the participants were informed about the objective of the study and the value of their responses for our study; they accepted, signed the informed consent, and were informed that their data would be used confidentially in this study.

The total number of participants was 16 . Three participants were interviewed via Microsoft Teams because only they accepted a synchronous interview. The average recording time was 38 minutes. The majority of the participants $(n=13)$ requested the interview guide to be sent through Google forms. These participants were sent the link via Google forms and they answered from the 16th to 18th of January. Then on January 24th and 25th, other seven replies were received; however, the data did not provide any new information, so the new replies were not included in the study. This number of participants indicated that the saturation principle had been reached (Álvarez-Gayou, 2003). Once the data was collected, it was interpreted following the steps proposed by Gibson and O'Connor (2017). The data collected in the interviews was transcribed, carefully read many times to be familiar with it and analyzed following a directed qualitative content analysis (Hsieh \& Shannon, 2005). The analysis followed these steps:
1. Organizing the data. In this step, the researchers read and revised the interview guide and started to identify the topic, which led to answering the research questions. Among them were participation frequency, feelings toward participation, and emotional factors that influence students' participation, technological problems, and connectivity problems. The topics were organized in a chart, so the analysis was easier to do and the responses for the research questions were obtained. Secondly, the ideas and topics identified were organized.

2. Finding and organizing ideas and concepts. Here, it was necessary to note the similarities and differences among the data; the ideas most commonly mentioned among the participants were selected. Finally, in the comparison across participants, data categories emerged. Table 1 shows a sample of the coding of the qualitative data.

3. Ensuring reliability and validity in the data analysis and the findings. In order to get a valid instrument, the interview questions were sent to three experts in research. Two of them belong to the Sistema Nacional de Investigadores (SNI); the other researcher has been in a research academy for seven years. Their comments allowed the researchers to be sure that the instrument would help to explore what was intended with the interview. Later, the researchers contacted some participants to ask if what the researchers had interpreted really reflected the voice of the participants. In that way, the researchers confirmed that the results were not biased, and they reflected what the participants meant in their replies.

4. Connecting findings. In this final step, the researchers looked for plausible explanations for findings. They summarized the findings and are the ones presented below. Moreover, the results were compared to the ones obtained in previous studies that explored participation in synchronous sessions and engagement and participation in the synchronous learner-to-facilitator interaction. 
Revista Caribeña de Investigación Educativa | 2021, 5(2), 52-67

Table 1. Coding process of the qualitative data

\begin{tabular}{|c|c|c|c|c|}
\hline Research question & Participant responses & Codes & Categories & Themes \\
\hline $\begin{array}{l}\text { RQ1. What are the students' per- } \\
\text { ceptions about active participation } \\
\text { in online synchronous sessions? }\end{array}$ & $\begin{array}{l}\text { "...you collaborate with the teach- } \\
\text { er... partners in the class...." (P13) }\end{array}$ & Collaborate & Collaborative & $\begin{array}{l}\text { Active partici- } \\
\text { pation percep- } \\
\text { tion }\end{array}$ \\
\hline $\begin{array}{l}\text { RQ2. What is the level of partic- } \\
\text { ipation in the student-to-teacher } \\
\text { interaction in online synchronous } \\
\text { sessions in a higher institution? }\end{array}$ & $\begin{array}{l}\text { "Almost never, I don't consider it } \\
\text { necessary" (P10) }\end{array}$ & Unnecessary & Low & $\begin{array}{l}\text { Degree of par- } \\
\text { ticipation }\end{array}$ \\
\hline \multirow{4}{*}{$\begin{array}{l}\text { RQ3. What factors affect student } \\
\text { participation while teachers are } \\
\text { lecturing? }\end{array}$} & $\begin{array}{l}\text { "...ensures that the topic at hand is } \\
\text { being understood..." (P7) }\end{array}$ & Understanding & Cognitive & \multirow{4}{*}{$\begin{array}{l}\text { Factors that } \\
\text { influence stu- } \\
\text { dent active } \\
\text { participation }\end{array}$} \\
\hline & $\begin{array}{l}\text { "I don't participate actively in class } \\
\text { when I can't understand all, I feel } \\
\text { confused and annoyed" (P4) }\end{array}$ & Annoyed & Emotional & \\
\hline & $\begin{array}{l}\text { "If the teacher asks me something } \\
\text { I answer, just because I respect } \\
\text { teachers" (P5) }\end{array}$ & Respect & Moral & \\
\hline & $\begin{array}{l}\text { "I did not reply... I lost internet } \\
\text { connection..., my computer's mi- } \\
\text { crophone is not working" (P3) }\end{array}$ & $\begin{array}{l}\text { Internet connec- } \\
\text { tion }\end{array}$ & Technical & \\
\hline
\end{tabular}

\section{Results}

The results are presented in three sections. In the first section, the students' perceptions about participation in online synchronous sessions are shown. In the second section, the level of participation is categorized and in the last section, the factors that influence students' active participation are displayed.

\subsection{Students' perceptions about active participa- tion in online synchronous sessions}

Most of the participants consider participation in the student-to-teacher interaction to be necessary. They think that participation in synchronous sessions is vital because they stay focused on the class, express and clear out doubts, ask teachers questions, understand and receive feedback, and get appealed and interested in the sessions. Students mention aspects necessary to interact (Salmon, 2011). Participants 1, 4, 13, 15 and 16 mentioned the following:

"I participate actively in online sessions when I have doubts." (P1)
"I participate because most of the time I get confused." (P4)

"In this way, you collaborate with the teacher in the class to increase your partners' knowledge and try to understand the topic." (P13)

"Definitely it is important because if we don't ask him or her, the teacher is like 'OK, my students understand everything, so I don't have problems to start with another topic'." (P15)

"If you don't act interactively you get bored, get distracted with your mobile or something else, so if you don't participate, you don't pay attention and you don't get the topic." (P16)

Others believe that participation is essential for their scores. Olaniran (2006) proposed to take participation as part of student grades to increase participation. Participants 3 and 11 commented:

"I participate because participation is important and required in classes." (P3)

"I participate because I wouldn't like my average to be affected." (P11) 
Other opinions about the importance of participation are more conditioned to the interest of the participant or if the teacher requires it. One participant said:

"I participate only when I'm asked to or if the topic is of my interest." (P6)

Other participants mentioned that feedback is important and through participation, they can get it. Participants 4 and 7 expressed it in this way:

"I participate because if we don't do it, there is no feedback." (P4)

"I participate in synchronous sessions because I like to get feedback on my participation." (P7)

On the other hand, a few participants consider that participation in the student-teacher interaction is unnecessary unless it is graded, or because of students' learning rhythm or because understanding is possible without participating. However, participation is essential to check comprehension and construct knowledge (McBrien et al., 2009). This is exemplified with the following extracts from participants 6,8 and 10:

"It is not necessary to participate actively in the synchronous sessions, unless it's a requirement linked to the student's grade." (P6)

"It is not really necessary to participate because as you follow your rhythm you do not have to say anything to the others because it is a personal way to learn." (P8)

"I don't consider it necessary to participate because I can understand even if I don't participate." (P10)

These comments tend to consider active participation important in synchronous sessions. However, it is also noticeable that some students do not consider it necessary. This assumption may be linked to the degree of participation students have in synchronous sessions, described in the following section.

\subsection{Degree of participation in the stu- dent-to-teacher interaction in online synchro- nous sessions}

According to the participants' answers, the degree of participation in online synchronous classes iss classified into three categories: high, moderate, and low. The first category is divided into two subcategories: knowledge-gaining element and class-compliance element.

Students showed highly active participation because they saw it to clear doubts, get feedback, interact, and understand. Thus active participation becomes a knowledge-gaining element. According to Chen et al. (2015), interaction between learners and teachers helps negotiate meaning and verify understanding. Some participants said:

"I participate because I have questions." (P1)

"I like to get feedback on my participation." (P7)

"I participate because in this way we keep the thread of the class, we have interaction, and we show that we're in class." (P12)

"I have an active participation in the class because sometimes the teacher explains to us but sometimes, I don't understand the concepts or the topics she is talking about, so I consider that I have an active participation in the class." (P15)

Other reasons that make students participate actively are categorized as a class-compliance element when it is mandatory and considered in their final grades. So, the strategy to consider participation in the summative evaluation increases participation (Olaniran, 2006). This is expressed in the following extracts:

"I participate because the participation is important and required in classes." (P3)

"I participate because I wouldn't like my average to be affected." (P11)

The second category is moderate, as the participants use adverbs such as sometimes and more or less to indicate their degree of participation. Students get into active participation when they face confusion, do not handle the information, or participate faster than participant 14. Another cause relates to an interest in the class or lack of it. Regarding interest, teachers are trying alternatives such as ARGs (Rafiq \& Hashim, 2018) and artificial intelligence (Pham, Pham, Nguyen \& Cao, 2018) to engage and attract 
students in online learning. This is represented with the following extracts from participants 4, 14 and 16.

"Sometimes I participate because most of the time I get confused." (P4)

"More or less. Because there [are] classes that I can participate, but there are classes that I don't know very well the topic, or I don't understand the teacher, or the other partners answer the questions, and I lose my turn.” (P14)

"Sometimes. If the topic was very interesting and I had an opinion or something like that, I participated. But if the topic was not interesting, I didn't participate or sometimes for example, if I didn't know the answer, I didn't say anything." (P16)

The last category is low. This category is subdivided into two subcategories: i) emotions involved and ii) active participants involved. The first subcategory is exemplified with participants 9, 10, 13, and 14 . These are their extracts:

\section{Emotions involved}

"Not at all. It depends how I feel and my motivation." (P9)
"Almost never, I don't consider it necessary." (P10)

"Not much. Sometimes because I do not feel sure of myself, I do not like to make mistakes, I know that making mistakes are part of learning, but I could not avoid it and I prefer to pay attention and listen to my partners." (P13)

"I think it depends on the student's mood because when you feel sick or bad, you don't answer, or you don't participate in the class." (P14)

The second subcategory is illustrated with the extracts from participants 2 and 8 :

\section{Active participants involved}

"Not really because other students tend to speak earlier than me." (P2)

"Not much because when we talk, we can bother the other classmates." (P8)

To better understand the students' perceptions about the degree of participation in synchronous sessions, Figure 1 graphically illustrates the categories that answer the second research question.

\section{Figure 1. Students' perceptions about the degree of participation in online synchronous sessions.}

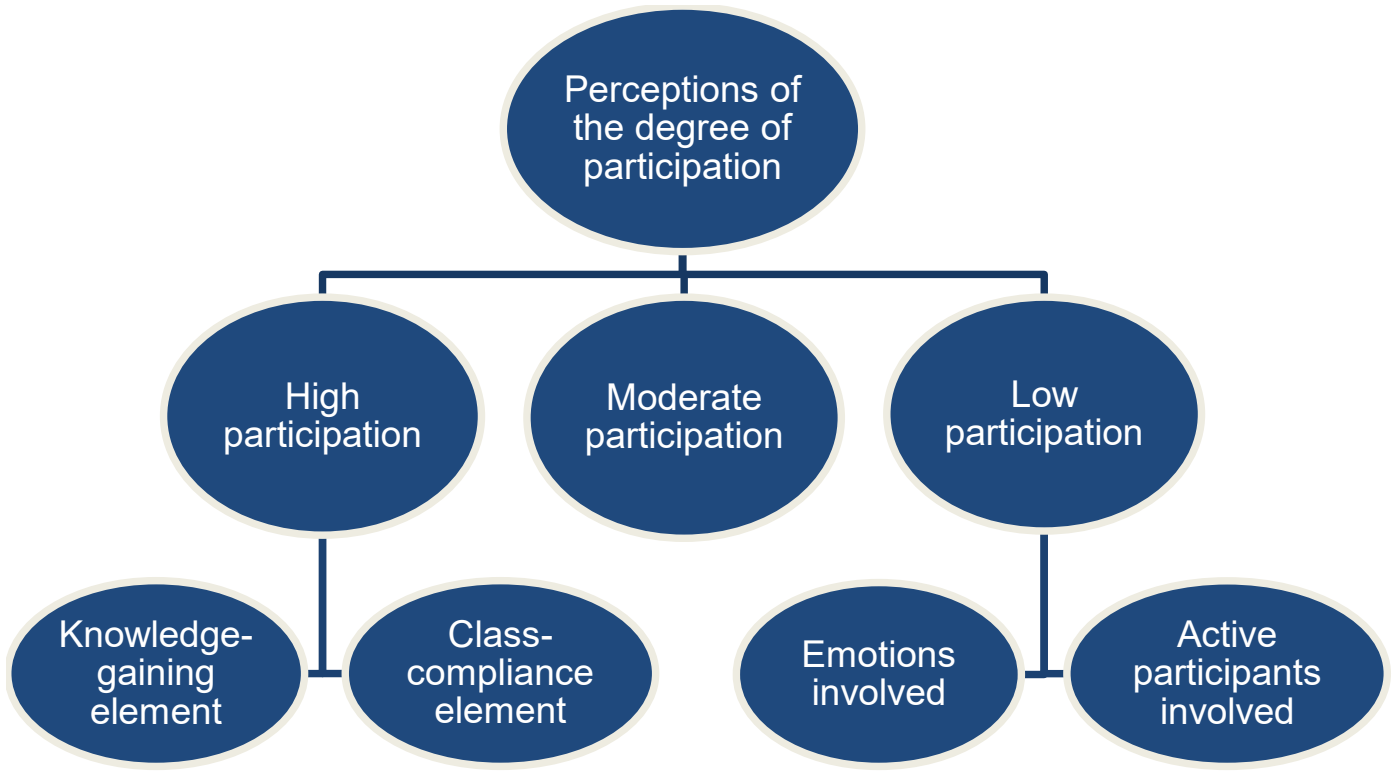

Note: Own elaboration 


\subsection{Factors that affect students' active participa- tion while teachers are lecturing}

From the analysis, the emerging factors that affect students' participation while teachers are lecturing in online synchronous sessions were classified into four types: affective factor, cognitive factor, moral factor and technical factor. Each type will be illustrated with different extracts taken from the participants' responses.

\subsubsection{Affective factor}

The affective factor is related to emotions, feelings or attitudes that participants mentioned in their responses. While teachers are lecturing, the affective factor positively affects students' participation, which can result in an improved relationship and attitude (Wu, 2017). Park and Bonk (2007) found that students valued the teachers' support, meaningful participation and spontaneous feedback from the teacher. Participant 4 commented:

"Even I feel distracted by all around me, but if my teacher asks me directly, I answer. I feel bad that the teacher has no answers from anyone." (P4)

However, the affective factor also affected the students' participation negatively such as affective filter outbreaks when the participant tried to interact. Participant 9 expressed:

"I don't reply because sometimes I'm afraid to say something wrong or the habit that anyone else is going to respond." (P9)

Some students' attitude was negative when teachers lecture so they do other things instead of being involved in the sessions, as Macnaught and Yates (2020) found. That happens when participants do not feel motivated to pay attention or when they consider that the topics are not interesting. Participants 11,15 and 16 said:

"When the teacher calls on me, I do not answer because I get distracted with other assignments, notifications or things." (P11)

"I Usually get bored during the class. I do other things or sometimes I am eating or watching the news while the teacher is speaking. I get distracted sometimes, but I don't pay attention at all." (P15)

"I sometimes participate. If the topic is very interesting and I had an opinion or something like that, I participated. But if the topic is not interesting, I don't participate." (P16)

\subsubsection{Cognitive factor}

The cognitive factor is related to the students' processing of information. For some participants, it takes a long time to provide a reply, which means that they work at their own pace $(\mathrm{Ng}, 2007)$. Participants 11,12 and 14 mentioned:

"In other cases, I don't know what to say or add because I am processing the information in my mind." (P11)

"Sometimes I talk to classmates about what we're learning or share opinions through a chat and pay attention. When the teacher asks for my participation, well, when I don't answer immediately is because I'm thinking what to say or even if I don't have the answer, I tell the truth." (P12)

"I try to connect the words that the teacher is saying in the moment, try to reflect on it and understand what he said." (P14)

Lack of understanding also affects students participation. Participants 2, 14 and 15 expressed the following:

"When I don't participate, most of the time is because I don't understand the topic, or I don't feel comfortable with my answer." (P2)

"When I don't participate, maybe I watch my phone or I have other things on my mind; in my case I create another word, a lot of things, crazy things maybe. When I return to reality I think 'Oh no, what is the answer?, oh God, help me' and I search faster for the answer in Google." (P14)

"Sometimes I don't reply because I usually don't have an idea what the answer is but when he asks me and I don't reply I think I feel bad, sad and many things. Many things cross my mind and I don't reply." (P15) 
It is important to deal with the cognitive factor because students interact with their teachers to negotiate meaning and verify understanding, which results in knowledge (Chen et al., 2015). In the same way, feedback and correction can be promoted (Ng, 2007).

\subsubsection{Moral factor}

The moral factor is related to the values that students demonstrate when they participate in synchronous sessions. It is worth mentioning that some students stay active in the student-teacher interaction because they respect their teacher. It is a way to show respect for the effort being made teaching online, as Wu (2017) found, students recognize that their teachers organized projects, provoked thought, and facilitated participation.

"Many of my teachers of this semester are doing their best and I think we need to participate to thank them, and because that makes everything easier. If the teacher asks me something, I answer, just because I respect teachers." (P5)

"I try to take notes and pay attention to everything they say because they obviously know what they are talking about. When teachers ask me something in particular, I always try to answer to show my respect for them." (P8)

\subsubsection{Technical factor}

According to the participants, the last factor that affects students' participation in synchronous sessions is the technical factor, which is linked to connectivity problems. Park and Bonk (2007) also found challenges such as peers' network connection problems and tool-related problems. Participants 2, 3, 5, 6, 7 and 13 expressed the following:

"Sometimes, I have internet problems." (P2)

"I take notes in my notebook, but there were moments when I did not reply when the teacher asked me because I lost internet connection, or I was distracted because my computer's microphone was not working." (P3)

"If I don't participate is because something is wrong with my internet." (P5)

"It may happen that I don't participate when my internet network is not working." (P6)

"I always answer, if my Wi-Fi fails, then I try to reconnect on the call and participate, explaining to my teacher why I couldn't answer at the time." (P7)

"Sometimes, I do not participate because I do not have a good internet connection and I do not understand the question.” (P13)

These extracts are portrayed in Figure 2, which depicts the factors that affect students' active participation while their teachers are lecturing in online synchronous sessions. 


\section{Figure 2. Factors that affect students' participation while teachers are lecturing}

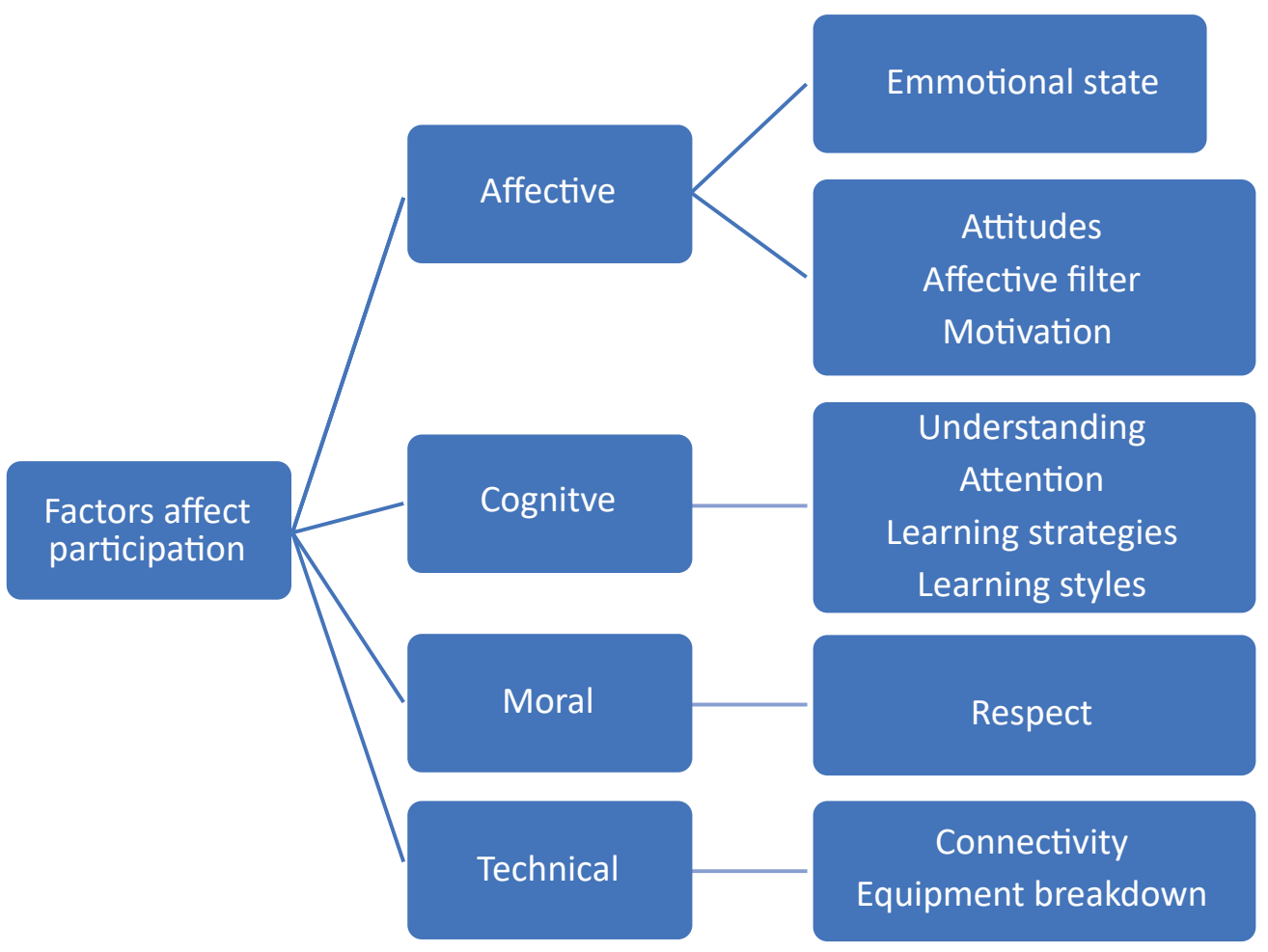

Note: Own elaboration

With the information provided in the previous sections, the three research questions that led our investigation have been answered. At the same time, the purpose of the study has been successfully achieved.

\section{Discussion}

The first research assumption indicated that students who actively participate in online synchronous sessions reflect more interest in terms of knowledge of the topic and their final grades. This assumption was supported with the categories active participation and moderate participation, which emerged from the analysis of the data. The participants expressed that they participated actively to solve doubts and understand the topics, receive feedback and remain interested in the sessions. This result is consistent with Moore's (1989), who considers that student-teacher interaction can help teachers test and feedback students, promote interaction, and keep students interested in what the instructor teaches and motivates students to learn. In addition, the participants mentioned that they participated actively because they did not want their grades to be affected. This is also supported by prior research that advises teachers to bolster student participation as part of the assessment process (Davidson-Shivers et al., 2001, Olaniran, 2006). According to the results of this study, the first research assumption is validated.

The second research assumption posed that students who do not participate actively in online synchronous sessions are not attentive to the contents of the class. Contrary to what was expected, the results of the study do not support this assumption. The results of the study suggest that different factors account for the lack of participation, namely, affective factors, cognitive factors, moral factors, and technical factors. The finding of technical factors is also consistent with Park and Bonk's (2007) study, 
which found specific challenges related to network connection problems. Another relevant finding that does not support the second assumption is related to the participants' learning styles. Some of them were grouped in the emerging category low participation since they expressed that they do not participate as much as the others. This result coincides with Juárez Díaz (2020) and Wang et al. (2018), who found that students' participation in synchronous sessions is low. Nonetheless, this low participation should not be understood as inattentive to the class since they pay attention and understand the contents of the lesson even though they do not actively participate. According to the results of this study, the second research assumption is not validated.

It is important to stress that due to the nature of this investigation, the results of the study are applicable to the specific sample of participants; therefore, they cannot be generalized to a larger population. Nevertheless, the findings of the study offer support to both validate prior research and elaborate on those factors that affect student participation in online synchronous sessions.

\section{Conclusions}

After analyzing the results of this study, two major conclusions were reached. First, it can be concluded that the level of participation in online synchronous classes in the context of this study is not balanced. The three resulting categories of the analysis (active participation, moderate participation, and low participation) represent the participants degree of participation, according to their extracts. Based on this finding of imbalanced degree of participation, one important teaching implication stands out: teachers should look for strategies fostering students' active participation in online synchronous sessions so that the participants may benefit from student-to-teacher interaction, as previous research suggests (Duncan et al., 2012; Ng, 2007; Anderson, 2003).

A second significant conclusion may be drawn from this study: the teaching model used in online synchronous sessions does not promote the stages that a virtual session must have: access and motivation, socialization, information exchange, knowledge construction, and development (Salmon, 2011). These stages are related to the affective, cognitive, and technical factors that emerged from this study. These factors seem to account for the lack of active participation, challenging the misconception that students are not attentive to the sessions. Some participants reported that they understand even when they do not participate actively, which suggests that collaborative work is not valued. This poses another teaching implication: teachers should consider different teaching strategies aimed at promoting collaborative work in online synchronous sessions.

Upon establishing the conclusions of this study, it may be appropriate to suggest further research topics in online synchronous sessions. First, because the results of this study cannot be generalized, it would be important to explore student participation in a different context from the one in this study. Second, more research regarding factors that affect active participation may be further explored in other teaching contexts to extend the theory in this area. Finally, in order to promote more active participation in online synchronous sessions, it would be valuable to explore new alternatives such as augmented reality, game-based learning and artificial intelligence.

\section{Acknowledgements/Recogni- tion:}

We deeply thank our participants for being part of this study. We also appreciate greatly the reviewers of the instrument.

\section{Bibliographical References}

Álvarez-Gayou, J. L. (2003). Cómo hacer investigación cualitativa. Fundamentos y Metodología. Paidós.

Anderson, T. (2003). Getting the mix right again: An updated and theoretical rationale for interaction. The International Review of Research in 
Open and Distributed Learning, 4(2). https://doi. org/10.19173/irrodl.v4i2.149.

http://www.irrodl.org/index.php/irrodl/article/view/149

Bautista, C. (2011). Proceso de investigación cualitativa: Epistemología, metodología y aplicaciones. Manual Moderno.

Burnett, C. (2003). Learning to chat: Tutor participation in synchronous online chat. Teaching in Higher Education. 8(2), 247-261.

https://doi.org/10.1080/1356251032000052474

Çakiroğlu, Ü. \& Kılıç, S. (2018). How to gamify? Example scenarios for participation in synchronous online learning. E-learning and Digital Media. 15(5), 254-266.

https://doi.org/10.1177/2042753018798166

Castillo-Montoya, M. (2016). Preparing for Interview Research: The Interview Protocol Refinement Framework. Qualitative Report 21(5).

https://doi.org/10.46743/2160-3715/2016.2337

Chen, P., Xiang, J., Sun, Y., Ban, Y., Chen, G., \& Huang, R. (2015). Exploring students' discussion in face to face and online synchronous learning. Emerging Issues in Smart Learning. Lecture Notes in Educational Technology. 183-191.

https://doi.org/10.1007/978-3-662-44188-6_26

Cunningham, U. (2014). Teaching the disembodied: Othering and activity systems in a blended synchronous learning situation. International Review of Research in Open and Distributed Learning, 15(6), 33-51. https://doi.org/10.19173/irrodl.v15i6.1793

Davidson-Shivers, G. V., Muilenburg, L. Y., \& Tanner, E. J. (2001). How do students participate in synchronous and asynchronous online discussions? Journal of Educational Computing Research, 25(4), 351-366.

https://doi.org/10.2190/6DCH-BEN3-V7CF-QK47

Duncan, K., Kenworthy, A., \& McNamara, R. (2012). The effect of synchronous and asynchronous participation on students' performance in online accounting courses. Accounting Education, 21(4), 431-449.

https://doi.org/10.1080/09639284.2012.673387
George-Reyes, C. E. (2021). Incorporación de las TIC en la Educación. Recomendaciones de organismos de cooperación internacional 1972-2018. RECIE. Revista Caribeña de Investigación Educativa, 5(1), 101-115.

https://doi.org/10.32541/recie.2021.v5i1.pp101-115

Gibson, N., \& O'Connor, H. (2017). A step-by-step guide to qualitative data analysis. A Journal of Aboriginal and Indigenous Community Health, 1(1), 64-90. https://r.issu.edu.do/l?l=103051MX

Hernández Sampieri, R., Fernández Collado, C., \& Baptista Lucio. P. (2014). Metodología de la investigación (6a ed.). McGraw Hill Education.

Hsieh, H. F., \& Shannon, S. E. (2005). Three approaches to qualitative content analysis. Qualitative health research, 15(9), 1277-1288.

https://r.issu.edu.do/l?1=108059W4

Hrastinski, S. (2006). The relationship between adopting a synchronous medium and participation in online group work: An exploratory study. Interactive Learning Environments. 14(2), 137-152.

https://doi.org/10.1080/10494820600800240

Holliman, R., \& Scanlon, E. (2006). Investigating cooperation and collaboration in near synchronous computer mediated conferences. Computers \& Education, 46, 322-335.

https://doi.org/10.1016/j.compedu.2005.11.002

Juárez Díaz, C. (2020). Online Teaching Experiences of Language Teachers in Higher Education in the Confinement Period. Revista De Estilos De Aprendizaje, 13(Especial), 43-55.

http://revistaestilosdeaprendizaje.com/article/view/2238

Juárez Díaz, C., \& Perales, M. (in press). Language Teachers' Emergency Remote Teaching Experiences during the COVID-19 Confinement. PROFILE.

Lee, L. (2002). Enhancing learners' communication skills through synchronous electronic interaction and task-based instruction. Foreign Language Annals, 35(1), 16-24.

https://doi.org/10.1111/j.1944-9720.2002.tb01829.x 
Macnaught, L. \& Yates, J. (2020). Designing student participation in synchronous writing instruction. International Journal of TESOL Studies. 2(2), 89-111. https://doi.org/10.46451/ijts.2020.09.08

Martin, F., Parker, M. A., \& Deale, D. F. (2012). Examining interactivity in synchronous virtual classrooms. International Review of Research in Open and Distributed Learning, 13(3), 227-261.

https://doi.org/10.19173/irrodl.v13i3.1174

McBrien, J., Cheng, R., \& Jones, P. (2009). Virtual Spaces: Employing a Synchronous Online Classroom to Facilitate Student Engagement in Online Learning. International Review of Research in Open and Distributed Learning, 10(3).

https://doi.org/10.19173/irrodl.v10i3.605

Moore, M. G. (1989). Editorial: Three types of interaction. American Journal of Distance Education, 3(2), 1-7. http://dx.doi.org/10.1080/08923648909526659

Ng, K. C. (2007). Replacing face-to-face tutorials by synchronous online technologies: Challenges and pedagogical implications. The International Review of Research in Open and Distributed Learning, 8(1). https://doi.org/10.19173/irrodl.v8i1.335

Olaniran, B. A. (2006). Applying synchronous computer-mediated communication into course design: Some considerations and practical guides. Campus-Wide Information Systems, 23(3), 210-220. https://doi.org/10.1108/10650740610674210

Pham, X. L., Pham, T., Nguyen, Q. M., Nguyen, T. H., \& Cao, T. T. H. (2018). Chatbot as an intelligent personal assistant for mobile language learning. In Proceedings of the 2018 2nd International Conference on Education and E-Learning (pp. 1621). https://doi.org/10.1145/3291078.3291115

Park, Y. J. \& Bonk, C. J. (2007). Synchronous learning experiences: Distance and residential learners' perspectives in a blended graduate course. Journal of Interactive Online Learning, 6(3), 245-264.

http://www.ncolr.org/jiol

Rafiq, K. R. M., \& Hashim, H. (2018). Augmented Reality Game (ARG), 21st-century skills and ESL classroom. Journal of Educational and Learning Studies, 1(1), 29-34.

http://journal.redwhitepress.com/index.php/jels/article/view/23

Salmon, G. (2011). E-moderating: The key to teaching and learning online ( $3^{\text {rd }}$. ed.). Routledge Falmer.

Simoff, S. J., \& Maher, M. L. (2006). Analysing participation in collaborative design environments. Journal of Design Studies, 1-20.

https://doi.org/10.1016/s0142-694x(99)00043-5

Stewart, A. R., Harlow, D. B. \& DeBacco, K. (2011). Students' experience of synchronous learning in distributed environments. Distance Education, 32(3), 357-381.

http://dx.doi.org/10.1080/01587919.2011.610289

Yang, S., \& Mei, B. (2018) Understanding learners' use of augmented reality in language learning: insights from a case study, Journal of Education for Teaching, 44(4), 511-513.

https://doi.org/10.1080/ 02607476.2018.1450937

Torun, E. D. (2013). Synchronous interaction in online learning environments with Adobe Connect Pro. Procedia-Social and Behavioral Sciences, 106, 2492-2499.

https://doi.org/10.1016/j.sbspro.2013.12.286

Wang, Q., Huang, C., \& Quek, C. L. (2018). Students' perspectives on the design and implementation of a blended synchronous learning environment. Australasian Journal of Educational Technology, $34(1)$.

https://doi.org/10.14742/ajet.3404

Watson, A. (2008). Developing teaching practice for more effective use of asynchronous discussion: A preliminary investigation. In Hello! Where are you in the landscape of educational technology? Proceedings ascilite Melbourne 2008. http://www.ascilite.org.au/ conferences/melbourne08/procs/watson.pdf

Wu, J. (2017). Teacher's presence in synchronous mobile chats in a Chinese university. The Journal of Asia TEFL, 14(4), 778-783. http://dx.doi.org/10.18823/ asiatefl.2017.14.4.13.778 


\section{JUÁREZ-DÍAZ • OJEDA-RUIZ}

Active Participation in the Student-to-Teacher Interaction in Online Synchronous Sessions...

\section{Appendix A}

Research questions and interview questions

\begin{tabular}{|c|c|}
\hline Research Question (RQ) & Interview questions \\
\hline & Introductory questions \\
\hline & $\begin{array}{l}\text { 1. Do you like to have online synchronous sessions? Why or Why not? } \\
\text { 2. How do you feel working in online synchronous sessions? } \\
\text { 3. How do you feel with the way teachers are working in online syn- } \\
\text { chronous sessions? } \\
\text { 4. When you are in online synchronous sessions, do you like to turn on } \\
\text { your camera? Why or Why not? } \\
\text { 5. How do you feel when teachers ask you to "turn on your camera"? }\end{array}$ \\
\hline & Key questions \\
\hline $\begin{array}{l}\text { RQ1. What are the students' perceptions about ac- } \\
\text { tive participation in online synchronous sessions? }\end{array}$ & $\begin{array}{l}\text { 6. Do you participate actively in online synchronous sessions? Why or } \\
\text { Why not? } \\
\text { 7. Do you consider it is necessary to participate actively in online syn- } \\
\text { chronous sessions? Why or Why not? }\end{array}$ \\
\hline $\begin{array}{l}\text { RQ2. What is the level of participation in the learn- } \\
\text { er-to-instructor interaction in online synchronous } \\
\text { sessions in a higher institution? }\end{array}$ & $\begin{array}{l}\text { 8. Do you express your doubts in online synchronous sessions? Why? } \\
\text { Why not? } \\
9 \text {. How often do you participate in online synchronous sessions? }\end{array}$ \\
\hline $\begin{array}{l}\text { RQ3. What factors affect student participation while } \\
\text { teachers are lecturing? }\end{array}$ & $\begin{array}{l}\text { 10. What do you usually do when your teachers are lecturing in the } \\
\text { videoconference? } \\
\text { 11. Do you participate in online synchronous sessions as much as you } \\
\text { do in face-to-face classes? Why or Why not? } \\
\text { 12. If you are participating less in online synchronous sessions than } \\
\text { you usually do in face-to-face classes, what has discouraged your par- } \\
\text { ticipation? } \\
\text { 13. If you are participating more in online synchronous sessions than in } \\
\text { face-to-face sessions, what has encouraged your participation? } \\
14 \text { Was there any time when your teacher asked for your participation } \\
\text { in online synchronous sessions, but you did not reply? If so, what pre- } \\
\text { vented you from answering your teacher? }\end{array}$ \\
\hline & Closing questions \\
\hline & $\begin{array}{l}\text { 15. Would you like to mention something else about your general per- } \\
\text { formance in online synchronous sessions? }\end{array}$ \\
\hline
\end{tabular}

\section{CÓMO CITAR:}

Juárez-Díaz, C., \& Quijano-López, R. (2021). Active Participation in the Student-to-Teacher Interaction in Online Synchronous Sessions in Higher Education. RECIE. Revista Caribeña de Investigación Educativa, 5(2), 52-67. https://doi.org/10.32541/recie.2021.v5i2.pp52-67 